\title{
Prediction of phase formation sequence and phase stability in binary metal-aluminum thin-film systems using the effective heat of formation rule
}

\author{
R. Pretorius, ${ }^{a)}$ A. M. Vredenberg, and F. W. Saris \\ FOM-Institute for Atomic and Molecular Physics, Kruislaan 407, 1098 SJ Amsterdam, The Netherlands \\ R. de Reus \\ Physics Department, Riso National Laboratory, DK-4000 Roskilde, Denmark
}

(Received 26 February 1991; accepted for publication 3 June 1991)

\begin{abstract}
The effective heat of formation $\left(\Delta H^{\prime}\right)$ concept allows heats of formation to be calculated as a function of concentration. In this work the effective heat of formation rule is used to predict first phase formation in metal-aluminum thin-film systems and to predict subsequent phase sequence for thin metal films on thick aluminum or thin aluminum on thick metal substrates. The effective concentration at the growth interface is taken to be that of the lowest temperature eutectic (liquidus) for the binary system. Although the effective heat of formation rule may predict that formation of a certain phase would lead to the largest free energy change, this phase does not necessarily form at the moving reaction interface if it has difficulty to nucleate. By excluding phases with a large number of atoms per unit cell and which thus have difficulty to nucleate, the effective heat of formation rule successfully predicts first phase aluminide formation for all 15 metal-aluminum binary systems for which experimental data could be found. It is also shown how the effective heat of formation rule can be used to predict formation and decomposition of aluminide phases in contact with each other or in contact with their component metals.
\end{abstract}

\section{INTRODUCTION}

There has been much interest in formulating rules for predicting first phase formation and subsequent phase sequence in binary metal-silicon ${ }^{1-5}$ and metal-metal ${ }^{6,7}$ thinfilm systems. One of the first rules ${ }^{1}$ was that of Walser and Bené which stated that:

"The first compound nucleated in planar binary reaction couples is the most stable congruently melting compound adjacent to the lowest-temperature eutectic on the bulk equilibrium phase diagram."

This rule was relatively successful in predicting first phase formation in metal-silicon systems and was extended by Tsaur $e t a l^{2}$ to subsequent phase formation sequence in metal-silicon systems using the smallest temperature difference between the liquidus curve and the peritectic (or peritectiod) point as a measure of stability when the compounds between the first phase and the remaining element are all noncongruently melting compounds. Bené subsequently extended the Walser-Bené rule to metal-metal systems ${ }^{6}$ by relaxing the requirement that the first phase that forms needs to be congruent. Later Ronay ${ }^{3}$ proposed a rule for first phase nucleation taking into account the central eutectic, diffusing species, and interfacial free energy. None of the above-mentioned rules did, however, make direct use of thermodynamic data and it was only after Pretorius ${ }^{4,5,7}$ proposed the effective heat of formation concept that thermodynamic data could be used directly to predict first phase formation and the subsequent phase sequence. The effective heat of formation rule enables the calculation of heats of formation as a function of concen-

\footnotetext{
On leave from the Ion-solid Interaction Division, Van de Graaff Group, National Accelerator Centre, P.O. Box 72, Faure 7131, South Africa.
}

tration and has been successful in predicting silicide phase formation sequence $e^{4,5}$ and to explain how the presence of impurities such as oxygen or small amounts of gold can alter phase formation sequence during nickel and cobalt silicide formation, respectively. ${ }^{5}$ It has also been useful in explaining why CoSi formation is dominant at low temperatures while the formation of $\mathrm{Co}_{2} \mathrm{Si}$ becomes significant at higher temperatures during ion-beam mixing in the Co-Si system. ${ }^{8}$ Recently the effective heat of formation concept was used to predict phase formation in Al-Ni systems. ${ }^{7}$ In this work we test the effective heat of formation rule by comparing its predictions against experimental data for metal-Al systems in general.

\section{THE EFFECTIVE HEAT OF FORMATION RULE}

The driving force for a process to take place is given by the change in the Gibbs free energy:

$$
\Delta G^{\circ}=\Delta H^{\circ}-T \Delta S^{\circ},
$$

where $\Delta H^{\circ}$ is the change in enthalpy during the reaction at temperature $T$ and $\Delta S^{\circ}$ the change in entropy. The change in enthalpy (or heat of formation) $\Delta H^{\circ}$ is, however, a good measure of the change in free energy $\Delta G^{\circ}$ because the change in entropy $\Delta S^{\circ}$ is usually only about $\pm 0.001 \mathrm{~kJ} /$ deg per mole of atoms during solid state formation of ordered compounds. ${ }^{9}$ The term $T \Delta S^{\circ}$ at a typical reaction temperature of $300^{\circ} \mathrm{C}$ is thus usually negligibly small when compared to heats of formation $\Delta H^{\circ}$ for most solid state reactions (see Tables I and II for aluminide $\Delta H^{\circ}$ values). It should therefore be possible to use heats of formation to predict phase formation when activation or nucleation barriers do not exist, as a system would always want to go to its lowest possible free energy state. During solid-state in- 


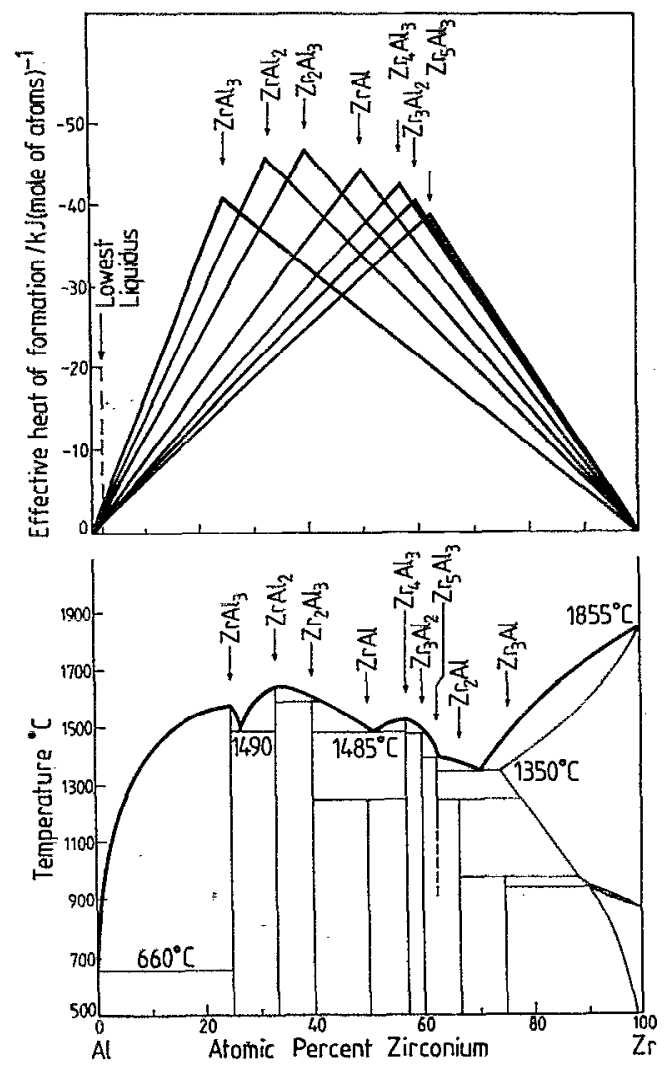

FIG. 1. The effective heat of formation $\left(\Delta H^{\prime}\right)$ diagram for compound phase formation (top) and the phase diagram (bottom) for the $\mathrm{Zr}$-Al system. Each triangle of the effective heat of formation diagram represents the energy released during the formation of a particular zirconium-aluminide phase as a function of concentration. The most negative $\Delta I^{\prime}$ values occur when the $\mathrm{Zr}$ and $\mathrm{Al}$ concentrations match that of a particular compound, as the ratio of effective concentration and compound concentration is unity [see Eq. (2)] and the effective heat of formation $\left(\Delta H^{\prime}\right)$ is then equal to the heat of formation $\left(\Delta H^{\circ}\right)$ expressed as $\mathrm{kJ}$ (mol at.) ${ }^{-1}$.

concentration, the two concentrations being linked by an activity coefficient. It is not possible to calculate what the actual effective concentrations of the reactants are at the growth interface during solid state interaction. Brown and Ashby have, however, shown that for a given structure and bond type, the activation energy for solid state diffusion is directly proportional to the melting point of the solid. ${ }^{12}$ Assuming that the pre-exponential factor in the diffusion coefficient is approximately thie same, the activation energy determines mobility. The greatest mobility of the atoms and the most effective mixing at a reaction interface upon heating is therefore expected to take place at the composition of the lowest eutectic (or liquidus) of the binary system. We therefore choose the effective concentrations of the interacting atoms to be that of the lowest temperature eutectic (liquidus). This is also the criterion used in the Walser-Bené phase formation rule. ${ }^{1}$ From the Al-Zr phase diagram (see Fig. 1) it can be seen that the lowest temperature on the liquidus curve is $660^{\circ} \mathrm{C}$, which corresponds to the melting point of pure aluminum. The relative concentrations of the reacting species at the growth interface are therefore expected to be very $\mathrm{Al}$ rich and in such a case (where there is not a lowest temperature eutectic) we arbitrarily choose an effective aluminum concentration of 98 at. \%. This is indicated by the arrow labeled lowest liquidus in the effective heat of formation diagram (top, Fig. 1). The first column of $\Delta H^{\prime}$ values in Table $\mathrm{I}$ has been calculated at this concentration ( 98 at. \% Al, 2 at. \% $\mathrm{Zr}$ ) and it can be seen that formation of the most Al-rich phase $\mathrm{ZrAl}_{3}$ gives the most negative effective heat of formation of $-3.28 \mathrm{~kJ}$ (mol at. $)^{-1}$ This is also the phase that is found to form experimentally. ${ }^{6,13,14}$ The rule for first phase formation thus states: ${ }^{7}$

"The first-compound phase to form during metal-metal interaction is the phase with the most negative, effective heat of formation $\left(\Delta H^{\prime}\right)$ at the concentration of the lowest temperature eutectic (liquidus) of the binary system."

\section{B. Phase formation sequence}

To illustrate how the effective heat of formation rule can be used to predict phase formation sequence, let us again consider the $\mathrm{Zr}-\mathrm{Al}$ system. For the case of a thin $\mathrm{Al}$ film on thick $\mathrm{Zr}(\mathrm{Al}<\mathrm{Zr})$ a stage during interaction will be reached when all the $\mathrm{Al}$ will be consumed during first phase $\mathrm{ZrAl}_{3}$ formation. At this stage the effective $\mathrm{Al}$ concentration at the $\mathrm{Zr} / \mathrm{ZrAl}_{3}$ interface is expected to decrease moving to the right of the effective heat of formation diagram (see Fig. 1) until an effective concentration of about 71 at. $\% \mathrm{Al}$ and 29 at. $\% \mathrm{Zr}$ is reached. At this concentration the effective heat of formation diagram shows that $\mathrm{ZrAl}_{2}$ formation should lead to the most negative effective heat of formation. After transformation of all the $\mathrm{ZrAl}_{3}$ to $\mathrm{ZrAl}_{2}$ the effective concentration of the atoms at the reaction interface is expected to move further to the $\mathrm{Zr}$-rich region until $\mathrm{Zr}_{2} \mathrm{Al}_{3}$ becomes the most likely phase to form. This process continues with subsequent phases richer in $\mathbf{Z r}$ being formed until the most zirconium-rich phase is formed. It has to be pointed out that unlike metal-silicon systems noncongruent phases are usually not skipped in metal-metal systems. ${ }^{6,15}$ For thin $\mathrm{Zr}$ films on thick $\mathrm{Al}$ ( $\mathrm{Zr}<\mathrm{Al}$ ) $\mathrm{ZrAl}_{3}$ is again expected to be the first phase to form. When all the $\mathrm{Zr}$ is consumed the effective concentration of Al will tend to be greater than the composition of $\mathrm{ZrAl}_{3}$ but as no further phases richer in $\mathrm{Al}$ exist no interaction is expected to take place and $\mathrm{ZrAl}_{3}$ is the first and only phase to form. The effective heat of formation rule for phase formation sequence in metal-metal systems is thus formulated ${ }^{7}$ as follows:

"After first-phase formation in metal-metal binary systems, the next phase to form at the interface between the compound phase and remaining element is the next phase richer in the unreacted element, which has the most negative effective heat of formation."

Unfortunately experimental data for phase formation sequence in the $\mathrm{Zr}-\mathrm{Al}$ system could not be found, but we find that the effective heat of formation rule generally predicts phase sequence successfully for nickel, ${ }^{7,15.16}$ palladium, ${ }^{17}$ platinum, ${ }^{18}$ and gold ${ }^{19}$ aluminides, except that skipping of certain phases is found for $\mathrm{Pd}, \mathrm{Pt}$, and $\mathrm{Au}$. It would seem that phases are skipped that are difficult to 
TABLE II. Heats of formation $\left(\Delta H^{\circ}\right)$ and effective heats of formation $\left(\Delta H^{\prime}\right)$ for various aluminides. The $\Delta H^{\prime}$ values have been calculated at the concentration of the lowest temperature eutectic (liquidus) of the binary system. For systems without a lowest eutectic a relative effective concentration of 98 at. $\% \mathrm{Al}$ and 2 at. \% metal is arbitrarily chosen, as $\mathrm{Al}$ has in these cases the lowest melting temperature on the liquidus curve. The phases for which the $\Delta H^{\prime}$ values are underlined are those that have been found to form first. References refer to work from which heats of formation $\left(\Delta H^{\circ}\right)$ were obtained. The number of atoms per unit cell are given in brackets behind each phase.

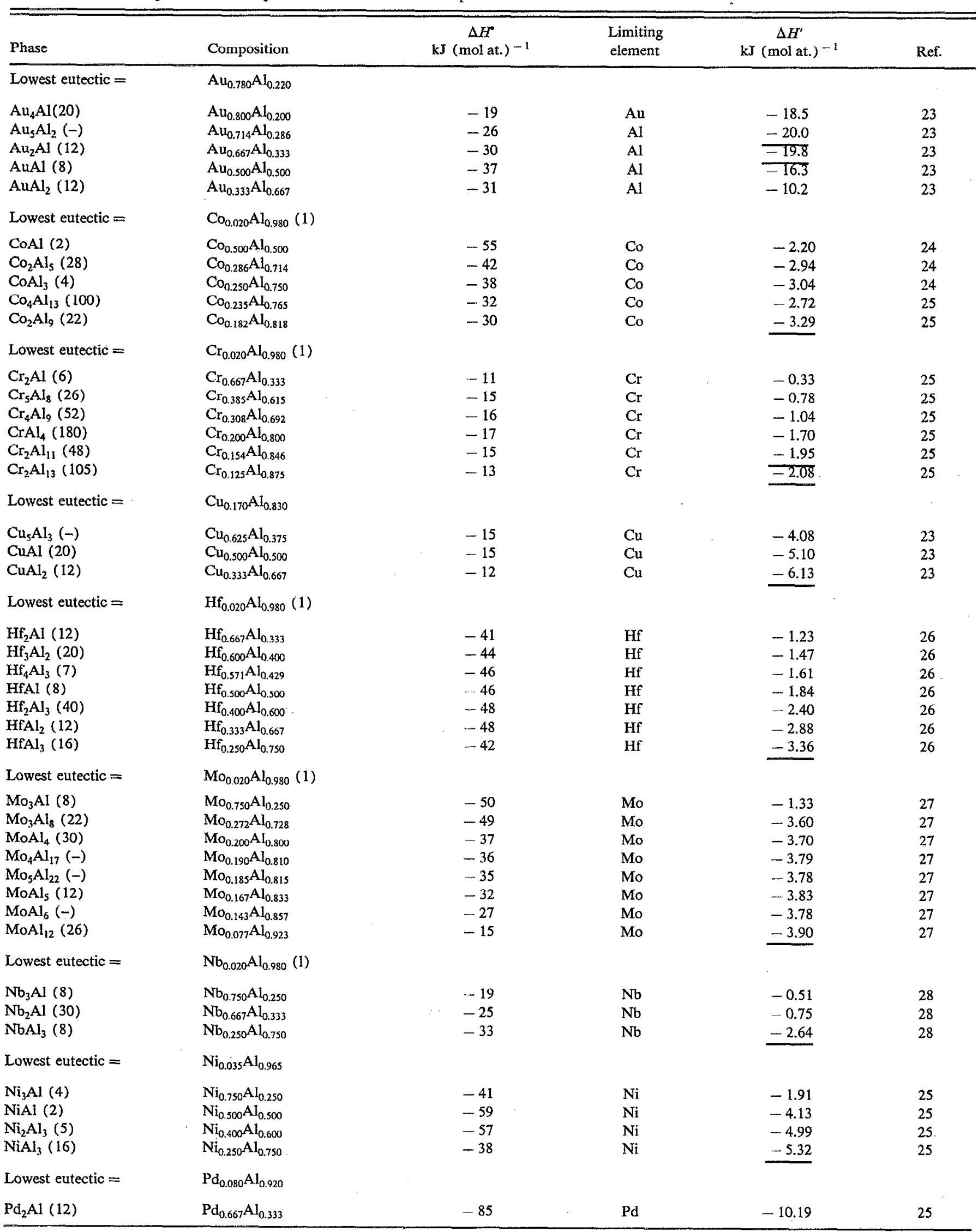




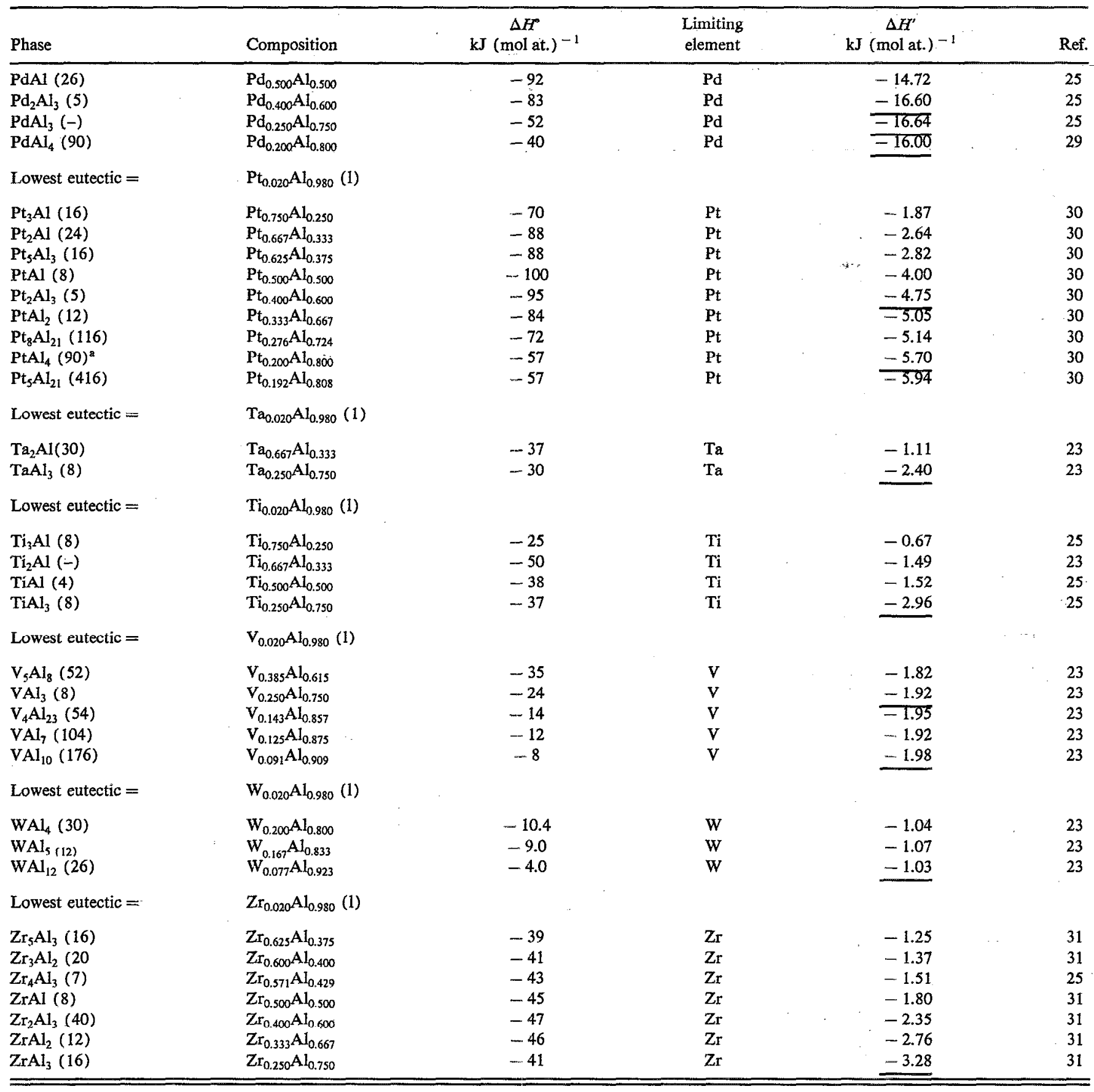

${ }^{2}$ Metastable phase.

nucleate which is usually indicated by a large number of atoms per unit cell or by noncongruency.

\section{Au-Al system}

Due to its importance in semiconductor device metallurgy, the Au-Al system has been the subject of considerable attention. The Au-Al phase diagram shows five stoichiometric compounds namely $\mathrm{Au}_{4} \mathrm{Al}, \mathrm{Au}_{5} \mathrm{Al}_{2}, \mathrm{Au}_{2} \mathrm{Al}$, $\mathrm{AuAl}$, and $\mathrm{AuAl}_{2}$ (see Fig. 2). Thin-film studies using Rutherford backscattering spectrometry and x-ray diffraction have been used to determine growth kinetics and phase formation sequence $e^{19-22}$ in this system. There is much uncertainty regarding first phase formation as certain measurements show that $\mathrm{Au}_{5} \mathrm{Al}_{2}$ and $\mathrm{Au}_{2} \mathrm{Al}$ start to grow simultaneously ${ }^{20}$ while others have found only $\mathrm{Au}_{5} \mathrm{Al}_{2}$ to be the first phase to form. ${ }^{19,21,22}$

Using the effective heat of formation concept to predict first phase formation we see that there is from a thermodynamic point of view hardly any difference between $\mathrm{Au}_{5} \mathrm{Al}_{2}$ and $\mathrm{Au}_{2} \mathrm{Al}$ formation (see effective heat of formation diagram in Fig. 2). At the composition of the lowest eutectic (78 at. \% Au, 22 at. \% Al) the $\Delta H^{\prime}$ value for $\mathrm{Au}_{5} \mathrm{Al}_{2}$ is $-20.0 \mathrm{~kJ}(\mathrm{~mol} \text { at. })^{-1}$ and -19.8 

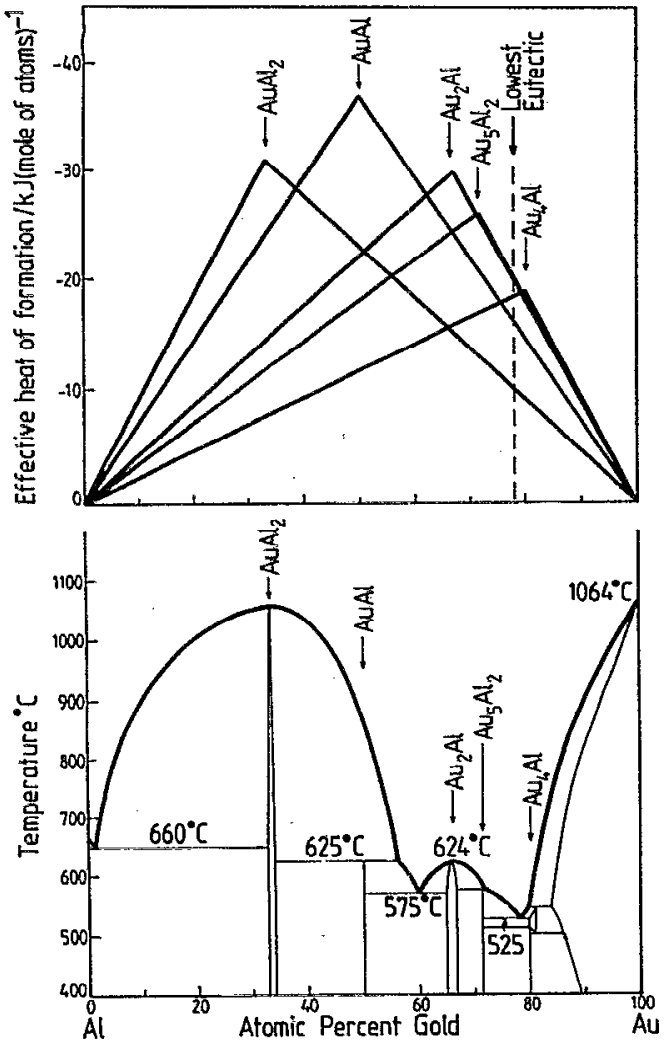

FIG. 2. Effective heat of formation diagram and phase diagram for the $\mathrm{Al}-\mathrm{Au}$ system. This system is very interesting as it is one of the few cases where the lowest eutectic (liquidus) is not $\mathrm{Al}$ rich.

$\mathrm{kJ}$ (mol at.) ${ }^{-1}$ for $\mathrm{Au}_{2} \mathrm{Al}$ (see Table II). This difference is negligibly small and differences in experimental conditions could thus favor formation of one or the other. This is confirmed by experimental results. ${ }^{19-22}$ The formation of both $\mathrm{Au}_{5} \mathrm{Al}_{2}$ and $\mathrm{Au}_{2} \mathrm{Al}$ as found by Campisano et al. ${ }^{20}$ is probably due to small variations in the effective concentrations laterally along the growth interface due to for instance impurities. If conditions are exactly identical along the entire growth interface, formation of only one phase would be expected.

The Bené rule ${ }^{6}$ states that the first phase nucleated in metal-metal thin-film reactions is the phase immediately adjacent to the low-temperature eutectic in the binary phase diagram. If we look at the $\mathrm{Au}-\mathrm{Al}$ binary phase diagram (bottom, Fig. 2) we see that the predicted first phase according to this rule is $\mathrm{Au}_{4} \mathrm{Al}$. As discussed above, the effective heat of formation rule correctly predicts either $\mathrm{Au}_{5} \mathrm{Al}_{2}$ or $\mathrm{Au}_{2} \mathrm{Al}$ (top, Fig. 2).

\section{Pt-Al system}

The Pt-Al system is very complicated with many equilibrium phases. ${ }^{11}$ In Table III some crystallographic and thermodynamic data are given for these phases with the high-temperature phases of $\mathrm{Pt}_{3} \mathrm{Al}, \mathrm{Pt}_{2} \mathrm{Al}$, and $\mathrm{PtAl}$ being omitted as thin-film interaction studies are usually carried out at temperatures below $800{ }^{\circ} \mathrm{C}$. From Table III and Fig. 3 it can be seen that the phase $\mathrm{Pt}_{5} \mathrm{Al}_{21}$ has the most negative effective heat of formation, namely -5.94
TABLE III. Crystallographic and thermodynamic data for equilibrium Pt-aluminide phases. The effective heats of formation $\left(\Delta H^{\prime}\right)$ have been calculated at a concentration of 2 at. $\% \mathrm{Pt}$ and 98 at. $\% \mathrm{Al}$.

\begin{tabular}{|c|c|c|c|c|c|}
\hline Phase & $\begin{array}{l}\text { Crystal } \\
\text { system }\end{array}$ & $\begin{array}{c}\text { Lattice } \\
\text { constants } \\
(\mathrm{nm})\end{array}$ & $\begin{array}{c}\text { Atoms } \\
\text { per } \\
\text { unit cell }\end{array}$ & $\begin{array}{c}\Delta H^{\circ} \\
\mathrm{kJ}(\mathrm{mol} \text { at. })^{-1}\end{array}$ & $\frac{\Delta H^{\prime}}{\mathrm{kJ}(\mathrm{mol} \text { at. })^{-1}}$ \\
\hline $\mathrm{Pt}_{3} \mathrm{Al}^{\mathrm{a}, \mathrm{b}}$ & tetrag. & $\begin{array}{l}0.5459 \\
0.7806\end{array}$ & 16 & -70 & -1.87 \\
\hline $\mathbf{P t}_{2} \mathrm{Al}^{\mathbf{a}}$ & orthor. & $\begin{array}{l}1.6306 \\
0.3919 \\
0.5433\end{array}$ & 24 & -88 & -2.64 \\
\hline $\mathrm{Pt}_{5} \mathrm{Al}_{3}$ & orthor. & $\begin{array}{l}0.541 \\
1.070 \\
0.395\end{array}$ & 16 & -88 & -2.82 \\
\hline$P t A l^{a, b}$ & cubic & 0.4866 & 8 & -100 & -4.00 \\
\hline $\mathrm{Pt}_{2} \mathrm{Al}_{3}^{\mathrm{b}}$ & hexag. & $\begin{array}{l}0.4209 \\
1.035\end{array}$ & 5 & -95 & -4.75 \\
\hline $\begin{array}{l}\mathrm{PtAl}_{2}^{\mathbf{b}} \\
\mathrm{Pt}_{8} \mathrm{Al}_{21}\end{array}$ & $\begin{array}{l}\text { cubic } \\
\text { tetrag. }\end{array}$ & $\begin{array}{l}0.5910 \\
1.297 \\
1.065\end{array}$ & $\begin{array}{r}12 \\
116\end{array}$ & $\begin{array}{l}-84 \\
-71\end{array}$ & $\begin{array}{l}-5.05 \\
-5.14\end{array}$ \\
\hline $\mathrm{Pt}_{5} \mathrm{Al}_{21}$ & cubic & $\cdots$ & 416 & -57 & -5.94 \\
\hline
\end{tabular}

Also has a high-temperature phase.

${ }^{b}$ Phases definitely observed in thin-film studies.

$\mathrm{kJ}(\mathrm{mol} \text { at. })^{-1}$. Its formation would thus be expected to lead to the largest change in free energy. Most thin-film studies do, however, show that $\mathrm{Pt}_{2} \mathrm{Al}_{3}$ is the first phase to form. ${ }^{18,32,33}$ This is very interesting since, in most cases, the
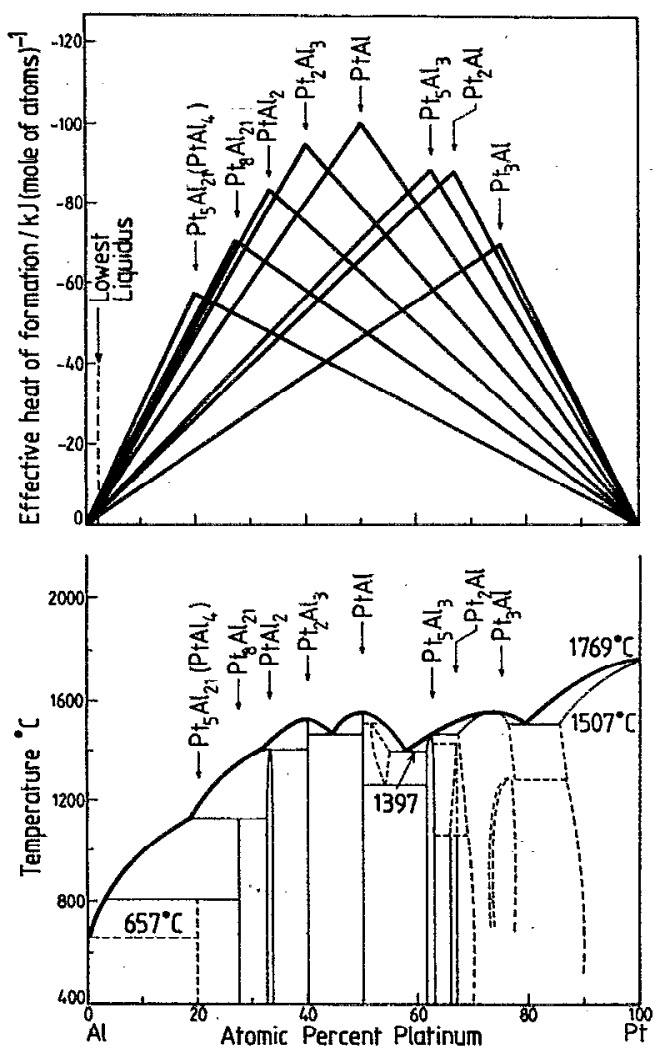

FIG. 3. The effective heat of formation and phase diagrams for the Pt-Al system. The compound $\mathrm{PtAl}_{4}$ is not an equilibrium phase and has only been observed after heating of thin-film structures. 
formation of the most $\mathrm{Al}$-rich phase $\left(\mathrm{Pt}_{5} \mathrm{Al}_{21}\right.$ in this case) is usually the norm for $\mathrm{Al}$ transition metal reaction, as can be seen from the excellent review article and thesis on aluminides by Colgan. ${ }^{34}$ Table III does, however, show that the $\mathrm{Pt}_{5} \mathrm{Al}_{21}$ phase has 416 atoms per unit cell, it would thus have great difficulty in nucleating, especially in a nonequilibrium situation, such as in thin-film systems, where growth has to take place at a moving interface. $\mathrm{The} \mathrm{Pt}_{8} \mathrm{Al}_{21}$ phase would also be difficult to nucleate as it has 116 atoms per unit (see Table III). Taking nucleation into consideration, the effective heat of formation rule would thus predict first phase formation of either $\mathrm{PtAl}_{2}$ (12 atoms per unit cell) or $\mathrm{Pt}_{2} \mathrm{Al}_{3}$ (5 atoms per unit cell). Their $\Delta H^{\prime}$ values are -5.05 and $-4.75 \mathrm{~kJ}(\mathrm{~mol} \text { at. })^{-1}$, respectively, and if it is kept in mind that thermodynamic quantities are seldom known with accuracies better than $10 \%$ it is clear that there is not much to choose between $\mathrm{PtAl}_{2}$ and $\mathrm{Pt}_{2} \mathrm{Al}_{3}$ formation from a thermodynamic point of view. It is nevertheless interesting that $\mathrm{Pt}_{2} \mathrm{Al}_{3}$ is usually found to form first instead of $\mathrm{PtAl}_{2}:{ }^{18,32,33}$

It has to be emphasized that the effective heat of formation rule predicts that if it were not for nucleation barriers, formation of the most Al-rich phase $\mathrm{Pt}_{5} \mathrm{Al}_{21}$ (see Table III) would lead to the largest change in free energy. In this context it is interesting that Howard et al. ${ }^{13}$ found that $\mathrm{PtAl}_{4}$, metastable phase with composition very close to that of $\mathrm{Pt}_{5} \mathrm{Al}_{21}$, is the first phase to form and that it grows parabolically with time between $250^{\circ} \mathrm{C}$ and $350^{\circ} \mathrm{C}$. Colgan, ${ }^{18}$ although finding $\mathrm{Pt}_{2} \mathrm{Al}_{3}$ first phase formation in thin-film systems, also observes subsequent $\mathrm{PtAl}_{4}$ formation at higher temperatures when he has an overall Al-rich stoichiometry. The $\mathrm{PtAl}_{4}$ phase, which is simpler than the $\mathrm{Pt}_{5} \mathrm{Al}_{21}$ phase ( 90 vs 416 atoms per unit cell) did not form until $450^{\circ} \mathrm{C}$. It appears that higher temperatures are needed to nucleate $\mathrm{PtAl}_{4}$ than $\mathrm{Pt}_{2} \mathrm{Al}_{3}$ which starts to form at $225^{\circ} \mathrm{C} .{ }^{18}$ This is understandable as higher temperatures lead to greater mobility and easier nucleation of phases, especially those with many atoms per unit cell. Because $\mathrm{PtAl}_{4}$ is a metastable phase it is difficult to determine its heat of formation. However, since $\mathrm{PtAl}_{4}$ has a composition very close to that of $\mathrm{Pt}_{5} \mathrm{Al}_{21}$ it can be expected, according to Miedema (see Ref. 23), that $\mathrm{PtAl}_{4}$ should have a heat of formation very close to that of $\mathrm{Pt}_{5} \mathrm{Al}_{21}$, namely -57 $\mathrm{kJ}(\mathrm{mol} \text { at. })^{-1}$ (see Table III). It is clear that the effective heat of formation rule is very successful in interpreting experimental observations in Pt-Al thin-film systems. ${ }^{13,18,32,33,35}$

As far as phase sequence is concerned, the effective heat of formation rule predicts that after first phase $\mathrm{Pt}_{2} \mathrm{Al}_{3}$ formation, this phase will continue growing until either all the $\mathrm{Al}$ or all the $\mathrm{Pt}$ is consumed. For thin $\mathrm{Al}$ on thick $\mathrm{Pt}(\mathrm{Pt}>\mathrm{Al})$, all the $\mathrm{Al}$ is consumed and the effective concentration of $\mathrm{Al}$ is expected to decrease, the relative concentrations of the reactants moving to the right of the effective heat of formation diagram (see Fig. 3 ) to a concentration region where $\mathrm{PtAl}$ formation leads to the biggest change in free energy. After transformation of all the $\mathrm{Pt}_{2} \mathrm{Al}_{3}$ to $\mathrm{PtAl}$ the effective concentration of the atoms moves further to the $\mathrm{Pt}$-rich region and $\mathrm{Pt}_{5} \mathrm{Al}_{3}$ formation is most likely to form at the $\mathrm{Pt} / \mathrm{PtAl}$ interface, followed by $\mathrm{Pt}_{2} \mathrm{Al}$, and finally $\mathrm{Pt}_{3} \mathrm{Al}$, as this is the most $\mathrm{Pt}$-rich phase. Experimental measurement shows that this is indeed the sequence of phase formation in the Pt-A1 system, although there is some uncertainty as to the formation of $\mathrm{Pt}_{5} \mathrm{Al}_{3}$ and $\mathrm{Pt}_{2} \mathrm{Al}^{18}{ }^{18}$ For structures with thin $\mathrm{Pt}^{-}$in contact with thick $\mathrm{Al}(\mathrm{Al}>\mathrm{Pt}), \mathrm{Pt}_{2} \mathrm{Al}_{3}$ is again predicted to form first until all the $\mathrm{Pt}$ is used up, followed by formation of $\mathrm{PtAl}_{2}$ and $\mathrm{PtAl}_{4}$. The phases $\mathrm{Pt}_{8} \mathrm{Al}_{21}$ and $\mathrm{Pt}_{5} \mathrm{Al}_{21}$ are not expected to form because of their difficulty to nucleate, as discussed above. Rutherford backscattering spectrometry and x-ray diffraction measurements do show that $\mathrm{Pt}_{2} \mathrm{Al}_{3}$ forms first, but that $\mathrm{PtAl}_{2}$ is then skipped, with $\mathrm{PtAl}_{4}$ formation taking place as the final phase. ${ }^{18} \mathrm{It}$ is, however, interesting to note that $\mathrm{PtAl}_{2}, \mathrm{Pt}_{8} \mathrm{Al}_{21}$, and $\mathrm{Pt}_{5} \mathrm{Al}_{21}$ are also all noncongruent phases and that in metal-silicon systems it is generally found that noncongruent phases are skipped. ${ }^{1,10}$

\section{E. Other binary metal-Al systems}

In Table II the heats of formation $\left(\Delta H^{\circ}\right)$ and effective heats of formation $\left(\Delta H^{\prime}\right)$ are given for metal-Al binary systems, for which heats of formation and experimental data regarding first phase formation could be found. It should be pointed out that the absolute values of $\Delta H^{\prime}$ are of no importance and that the effective heats of formation should only be compared for a particular binary system. The phases for which the $\Delta H^{\prime}$ values are underlined are those that have been found experimentally to have formed first. In Table IV these results are summarized. The predicted phases are those with the most negative effective heat of formation. More than one phase is predicted in those cases where other phases have $\Delta H^{\prime}$ values within $5 \%$ of the most negative effective heat of formation. Phases with a large number of atoms per unit cell (such as $\mathrm{Pt}_{8} \mathrm{Al}_{21}$ and $\mathrm{Pt}_{5} \mathrm{Al}_{21}$ ) are not expected to be the first phase to form, even though they may have the most negative $\Delta H^{\prime}$ values. This is because they are difficult to nucleate. In the case of the $\mathrm{Pt}-\mathrm{Al}$ system, therefore, $\mathrm{PtAl}_{2}$ is taken as the phase with the most negative effective heat of formation.

From Table IV it is clear that in every case, the effective heat of formation rule correctly predicts the observed first phase formation. It is also interesting to note that in the case of the $\mathrm{Au}-\mathrm{Al}$ system, where both $\mathrm{Au}_{5} \mathrm{Al}_{2}$ and $\mathrm{Au}_{2} \mathrm{Al}$ are predicted and where the difference between their $\Delta H^{\prime}$ values are very small, both phase have been found to form first or simultaneously. ${ }^{19-22}$ The same applies to the Pd system. The Mo-Al system is also very interesting as there is a very small difference from a thermodynamic point of view, between five different phases ranging from $\mathrm{Mo}_{4} \mathrm{Al}_{17}$ to $\mathrm{MoAl}_{12}$. Although $\mathrm{MoAl}_{12}$ has been found to be the first phase to form, ${ }^{40,50}$ the system is expected to be very sensitive to factors such as impurities which can affect the effective concentrations of the reactants and thus swing the first phase formation to one of the other phases.

From the second row of Table IV it can be seen that with the exception of the Au-Al system.all the metal-Al binary systems have a lowest temperature eutectic (or liquidus) which is overwhelmingly $\mathrm{Al}$ rich. The effective 
TABLE IV. Comparison of observed first phase formation and predicted first phase in metal-aluminum systems using the effective heat of formation $\left(\Delta H^{\prime}\right)$ rule. The effective heat of formation is calculated at the concentration of the lowest temperature eutectic (liquidus) of the binary phase diagram. The predicted phases are those with effective heats of formation $\left(\Delta H^{\prime}\right)$ within. $5 \%$ of the most negative $\Delta H^{\prime}$ (see Table II).

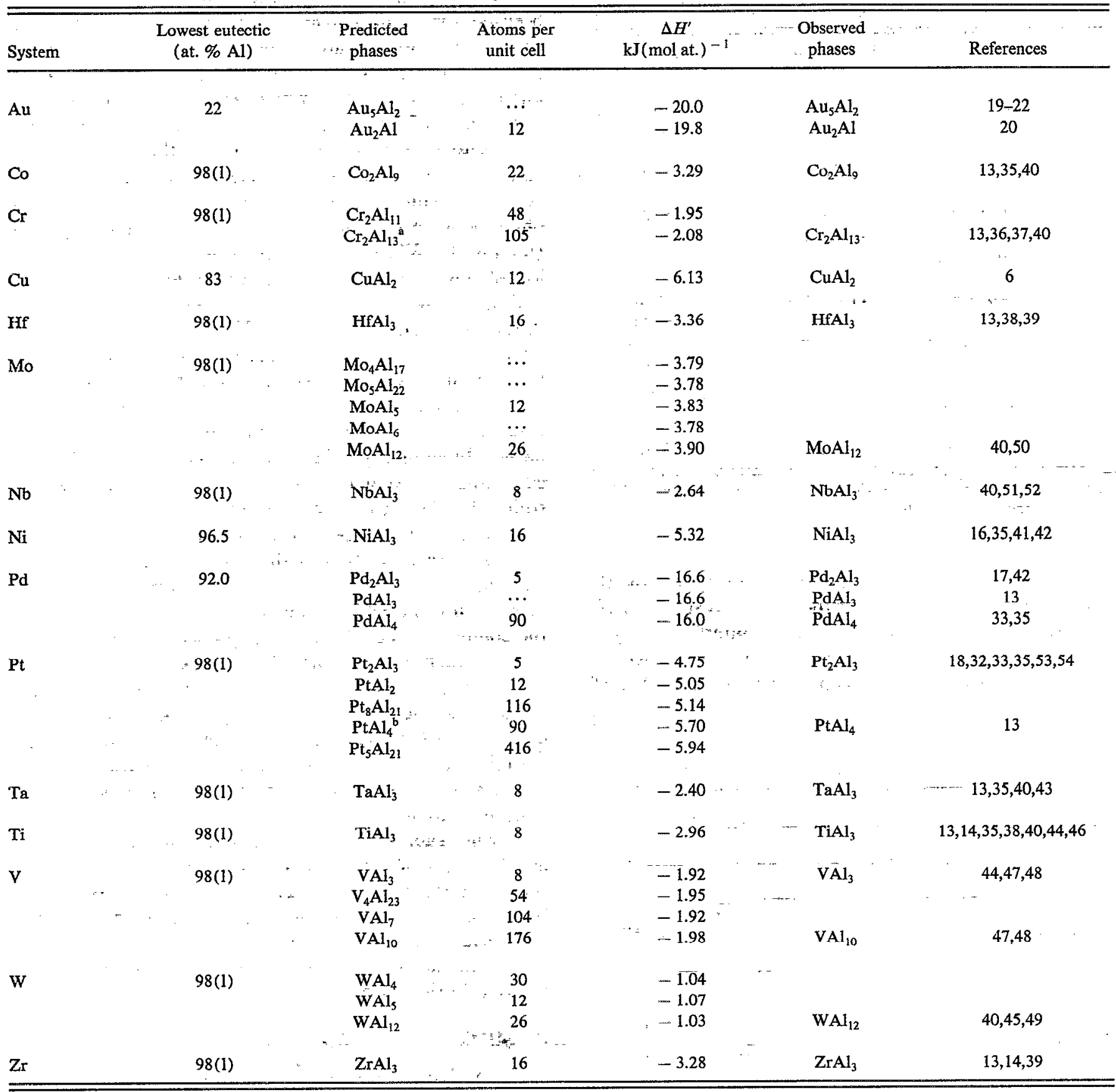

"This phase is identical to $\mathrm{CrAl}_{7}$ which is the phase referred to in older Refs. (34 and 40).

Metastable phase.

heat of formation rule for first phase formation thus explains in a quantitative way why the Al-rich phase is usually always favored.

\section{F. Decomposition}

Colgan $^{34}$ has measured formation and decomposition of several aluminide phases in contact with each other or in contact with their component metals. In Table $\mathrm{V}$ his experimental results are compared with effective heat of formation first phase predictions: To illustrate the use of the effective heat of formation rule in such structures we will discuss the Ni-Al system.

The effective heat of formation diagram for the $\mathrm{Ni}-\mathrm{Al}$ binary system is given in Fig. 4, with the composition of the different structures that have been investigated represented schematically above. During heating of the $\mathrm{Al} / \mathrm{Ni}_{3} \mathrm{Al}$ structure, mixing at the interface is again, as was the case for $\mathrm{Ni} / \mathrm{Al}$ samples, expected to take place (see Fig. 4) at the concentration of the lowest eutectic (3.5 at. $\% \mathrm{Ni}, 96.5$ at. $\% \mathrm{Al}$ ). At this effective concentration 
TABLE V. Decomposition of aluminide phases in contact with each other or in contact with their component metals. The predicted phase was obtained using the effective heat of formation rule in conjunction with the concentration of the lowest melting point eutectic of the binary system.

\begin{tabular}{|c|c|c|c|}
\hline System & Sample & Predicted phases & Observed phase \\
\hline $\mathrm{Ni}$ & $\begin{array}{c}\mathrm{Al} / \mathrm{Ni}_{3} \mathrm{AI} \\
\mathrm{NiAl}_{3} / \mathrm{Ni} \\
\mathrm{NiAl}_{3} / \mathrm{Ni}_{3} \mathrm{Al} \\
\mathrm{Al} / \mathrm{NiAl} / \mathrm{Ni}\end{array}$ & $\begin{array}{l}\mathrm{NiAl}_{3} \\
\mathrm{Ni}_{2} \mathrm{Al}_{3} \\
\mathrm{Ni}_{2} \mathrm{Al}_{3} \\
\mathrm{NiAl}_{3}\end{array}$ & $\begin{array}{l}\mathrm{NiAl}_{3} \\
\mathrm{Ni}_{2} \mathrm{Al}_{3} \\
\mathrm{Ni}_{2} \mathrm{Al}_{3} \\
\mathrm{NiAl}_{3}\end{array}$ \\
\hline$P d$ & $\begin{array}{c}\mathrm{Al} / \mathrm{Pd}_{2} \mathrm{Al} \\
\mathrm{Al} / \mathrm{PdAl} / \mathrm{Pd} \\
\mathrm{Pd}_{2} \mathrm{Al}_{3} / \mathrm{Pd}\end{array}$ & $\begin{array}{c}\mathrm{Pd}_{2} \mathrm{Al}_{3}, \\
\mathrm{Pd}_{2} \mathrm{Al}_{3}, \\
\mathbf{P d A l} l_{3}, \mathrm{PdAl}_{4} \\
\mathbf{P d A l}\end{array}$ & $\begin{array}{c}\mathrm{Pd}_{2} \mathrm{Al}_{3} \\
\mathrm{Pd}_{2} \mathrm{Al}_{3} \\
\mathrm{PdAl}\end{array}$ \\
\hline $\mathrm{Pt}$ & $\begin{array}{c}\mathrm{Al} / \mathrm{Pt}_{2} \mathrm{Al} \\
\mathrm{PtAl}_{2} / \mathbf{P t} \\
\mathrm{Al} / \mathrm{Pt}_{5} \mathrm{Al}_{21} / \mathbf{P t} \\
\mathrm{Pt}_{2} \mathrm{Al}_{3} / \mathbf{P t}\end{array}$ & $\begin{array}{c}\mathrm{PtAl}_{2}, \mathrm{Pt}_{2} \mathrm{Al}_{3} \\
\mathrm{PtAl}_{2}, \mathrm{Pt}_{2} \mathrm{Al}_{3} \\
\mathrm{PtAl}_{2}, \mathrm{Pt}_{2} \mathrm{Al}_{3} \\
\mathbf{P t A l}\end{array}$ & $\begin{array}{c}\mathrm{Pt}_{2} \mathrm{Al}_{3} \\
\mathrm{Pt}_{2} \mathrm{Al}_{3} \\
\mathrm{Pt}_{2} \mathrm{Al}_{3} \\
\mathrm{PtAl}\end{array}$ \\
\hline $\mathrm{Ti}$ & $\mathrm{Al} / \mathrm{TiAl} / \mathrm{Ti}$ & $\mathrm{TiAl}_{3}$ & $\mathrm{TiAl}_{3}$ \\
\hline $\mathbf{V}$ & $\mathrm{Al} / \mathrm{VAI}_{10} / \mathrm{V}$ & $\mathrm{VAl}_{3}$ & $\mathrm{VAl}_{3}$ \\
\hline
\end{tabular}

${ }^{a}$ References: Ni(16), Pd(17), Pt(18), Ti and V from E. G. Colgan, Ph.D. thesis, Cornell University, 1987.

$\mathrm{NiAl}_{3}$ is expected to be the first phase to form as was the case for the $\mathrm{Ni} / \mathrm{Al}$ system. For the $\mathrm{NiAl}_{3} / \mathrm{Ni}$ structure the effective concentration at the reaction interface is again controlled by the lowest eutectic, and will be on the Al-rich side within the $\mathrm{NiAl}_{3}$ to $\mathrm{Ni}$ concentration range. The ef-

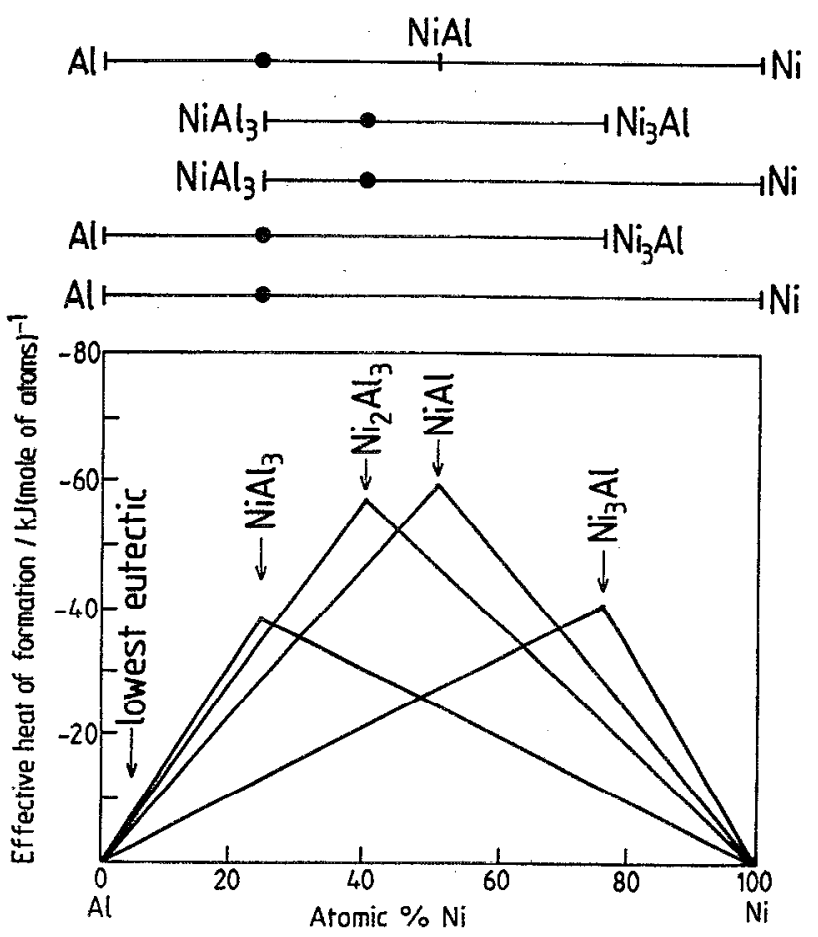

FIG. 4. The Ni-Al effective heat of formation diagram. Various structures for which phase formation and decomposition have been studied are shown at the top. The first phase formed in each case is indicated by the dot on the concentration axis. fective heat of formation diagram in Fig. 4, therefore, predicts that $\mathrm{Ni}_{2} \mathrm{Al}_{3}$ should form. The situation is similar to that for thin $\mathrm{Al}$ on thick $\mathrm{Ni}$, after all the aluminum has been consumed during first phase $\mathrm{NiAl}_{3}$ formation. The effective heat of formation rule for phase sequence states that the phase formed will be the next phase richer in the unreacted element (Ni), which has the most negative effective heat of formation. For the $\mathrm{NiAl}_{3} / \mathrm{Ni}_{3} \mathrm{Al}$ structure the effective concentration is again controlled by the lowest eutectic, which is on the Al side of the phase diagram. $\mathrm{Ni}_{2} \mathrm{Al}_{3}$ is again expected to form as it is the most Al-rich phase between the compositions of the two initial phases (see Fig. 4). When an Al/NiAl/Ni structure is heated, the lowest eutectic of the $\mathrm{Al} / \mathrm{Ni}$ system being at 96.5 at. \% $\mathrm{Al}$ will again cause an Al-rich effective concentration at the $\mathrm{Al} / \mathrm{NiAl}$ interface leading to $\mathrm{NiAl}_{3}$ formation. At the $\mathrm{NiAl} / \mathrm{Ni}$ interface the only phase that can form is $\mathrm{Ni}_{3} \mathrm{Al}$; however, its reaction rate is expected to be much slower, as the interface composition is further away from the lowest eutectic and less mobility of the atoms can thus be expected. In summary, whatever the configuration of a specific sample, mixing at the interface(s) will always be controlled by the lowest temperature eutectic of the system and the effective concentrations will be expected to be as close as possible to that of the lowest cutectic within the concentration range of the two interacting phases. This will be so even if the eutectic composition does not lie between the compositions of the interacting phases. Phases will react with each other to form the most Al-rich phase (with the exception of the Au-Al system where the lowest eutectic is on the Au-rich side of the phase diagram) with a composition lying between that of the interacting phases. Reaction to form a phase outside this composition range can only lead to an increase in free energy, as it leads to less bond formation.

From Table $V$ it can be seen that in every case the effective heat of formation rule $\left(\Delta H^{\prime}\right)$ correctly predicts the initial phase formation. This is in contrast to the efforts by Colgan ${ }^{16-18,34}$ who was unsuccessful when trying to use equilibrium thermodynamics and without taking concentration into account to predict phase formation and decomposition in these structures.

\section{SUMMARY AND CONCLUSION}

The effective heat of formation concept makes it possible to calculate heats of formation as a function of the relative concentrations of the reactant-atomic species. As phase formation during solid state interaction is a dynamic nonequilibrium process, an effective concentration at the growth interface is defined that differs from the true physical concentrations at the growth interface. This is similar to the effective concentration concept in solution chemistry where the effective concentration is linked to the true concentration by an activity coefficient. Although the effective concentrations could be influenced by many factors such as impurities, diffusing species, diffusivity, kinetics, temperature, etc., the overriding factor apparently affecting concentrations at a growth interface is the lowest temperature eutectic (or liquidus when the lowest eutectic temperature 
is not the lowest on the liquidus curve). We therefore choose the concentration at the lowest eutectic (liquidus) as the effective concentration at the growth interface, as mixing and interdiffusion is most likely to occur at such a concentration during heating. This criterion is also used by Walser and Bené in their rules for prediction of phase formation. ${ }^{1,6}$ Because the entropy change during solid state interaction is usually very small, the heat of formation is a good measure of the free energy change for the system. Although the effective heat of formation rule for first phase formation may predict that formation of a particular phase would lead to the largest free energy change, the phase may not be able to form due to a nucleation barrier. This is for instance the case for the Pt-Al binary system where the effective heat of formation rule predicts that $\mathrm{Pt}_{5} \mathrm{Al}_{21}$ and $\mathrm{Pt}_{8} \mathrm{Al}_{21}$ have the most negative effective heats of formation (see Table III). These phases do, however, have 416 and 116 atoms per unit cell, respectively, and would thus have great difficulty to nucleate at a moving interface. If such phases are excluded, the effective heat of formation rule predicts first phase formation correctly for all 15 metalaluminum binary systems for which experimental data could be obtained (see Table IV). In nearly all the cases the most Al-rich phase is formed first (see Table II), due to the fact that the lowest eutectic (liquidus) is always at a composition that is very aluminum-rich (with the exception of $\mathrm{Au}$ ), namely between 83 and 100 at. \% Al. Exceptions are $\mathrm{V}, \mathbf{P d}$, and $\mathbf{P t}$ as their most $\mathrm{Al}$-rich phases are difficult to nucleate because of the large number of atoms per unit cell. The Au-Al system is very interesting as it is the only one that has a lowest eutectic (liquidus) that is not $\mathrm{Al}$ rich (22 at. \% $\mathrm{Al}, 78$ at. \% Au). The effective heat of formation rule predicts that there is from a thermodynamic point of view little to choose between the formation of $\mathrm{Au}_{5} \mathrm{Al}_{2}$ and $\mathrm{Au}_{2} \mathrm{Al}$ and this is supported by experimental results where the formation of $\mathrm{Au}_{5} \mathrm{Al}_{2}$ (Refs. 19, 21, and 22) and $\mathrm{Au}_{2} \mathrm{Al}$ (Ref. 20) has been found. The same applies to the $\mathrm{Pd}-\mathrm{Al}$ system where $\mathrm{Pd}_{2} \mathrm{Al}_{3}, \mathrm{PdAl}_{3}$, and $\mathrm{PdAl}_{4}$ are predicted and have been found to form (see Table IV) as first phases. $13,17,26,33$

Unlike the Walser and Bené rules, ${ }^{1,6}$ which are rather empirical, the effective heat of formation rule makes direct use of thermodynamic data. It in effect gives a quantitative reason for the relatively large margin of success of the Walser and Bené rules. ${ }^{1,6}$ The more accurate predictions achievable with the effective heat of formation rule is clearly illustrated by the Au-Al system.

The phase formation sequence in binary metal-aluminum thin-film systems depends on the overall composition of the structure. For thin $\mathrm{Al}$ films on thick metal $(\mathrm{M}>\mathrm{Al})$ the first phase to form is the one predicted by the effective heat of formation rule, which is usually $\mathrm{Al}$ rich. After all the $\mathrm{Al}$ is used up during first phase formation the effective concentration of $\mathrm{Al}$ at the growth interface decreases and the next phase to form is the next phase richer in the unreacted metal, which has the most negative effective heat of formation. This continues until all of the first phase is used up during formation of the second phase. This process continues with subsequent phases richer in the unreacted metal being formed until the most metal rich (lowest $\mathrm{Al}$ content) is formed. For thin metal films on thick $\mathrm{Al}$ ( $M<A 1)$, the same first phase formation takes place but now $\mathrm{Al}$ is the remaining element and the effective concentration tends to be more Al rich leading to formation of the adjacent phase which is more Al rich, the process ending when the most Al-rich phase has formed. However, since the most Al-rich phase is usually the first phase to form no subsequent phase formation takes place. Phase skipping does not take place in cases such as $\mathrm{Ni}$, but for $\mathrm{Pd}, \mathrm{Pt}$, and $\mathrm{Au}$, skipping is found to occur for phases that are difficult to nucleate, which is usually indicated by a large number of atoms per unit cell or by noncongruency.

The effective heat of formation concept has also been found to be very successful in predicting phase formation or stability of aluminide phases in contact with each other or with their component metals. It is found that whatever the configuration of a specific sample, phase formation is controlled by the lowest eutectic (liquidus) and the effective concentrations at the growth interface is expected to be as close as possible to that of the lowest temperature eutectic (liquidus) within the concentration range of the two interacting phases. Phases will thus react with each other to form a phase with a composition between that of the interacting phases and closest to that of the lowest eutectic (liquidus) composition.

To summarize, the effective heat of formation concept enables the calculation of heats of formation as a function of concentration. By using the composition of the lowest eutectic (liquidus) of the binary system as a measure of the relative effective concentrations of the reactants, rules can be formulated to predict first phase formation and phase formation sequence. The effective heat of formation rule used in conjunction with ease of nucleation (complex phases with large numbers of atoms per unit cell have problems nucleating, especially at a moving interface) successfully predicts first phase formation, phase formation sequence, and decomposition of phases for all 15 metalaluminum binary systems for which experimental data could be found.

\section{ACKNOWLEDGMENTS}

One of us (R. P.) would like to thank the Foundation for Research Development of the Council for Scientific and Industrial Research (Pretoria) for financial assistance. The work at the FOM-Institute is part of the research program at FOM and was made possible by financial support from the Nederlandse Organisatie voor Wetenschappelijk Onderzoek. A portion of this work was performed at Riso National Laboratory and supported by the European Economic Community Science Plan.

\footnotetext{
${ }^{1}$ R. M. Walser and R. W. Bené, Appl. Phys. Lett. 28, 624 (1976).

${ }^{2}$ B. Y. Tsaur, S. S. Lau, J. W. Mayer, and M.-A. Nicolet, Appl. Phys. Lett. 38, 922 (1981).

${ }^{3}$ M. Ronay, Appl. Phys. Lett. 42, 577 (1983).

${ }^{4}$ R. Pretorius, Mater. Res. Soc. Proc. 25, 15 (1984).

${ }^{5}$ R. Pretorius, Vacuum 41, 1038 (1990).

${ }^{6}$ R. W. Bené, Appl. Phys. Lett. 41, 529 (1982).
} 
${ }^{7}$ R. Pretorius, R. de Reus, A. M. Vredenberg, and F. W. Saris, Mater. Lett. 9, 494 (1990).

${ }^{8}$ W. Xia, C. A. Hewett, M. Fernandes, S. S. Lau, and D. B. Poker, J. Appl. Phys. 65, 2300 (1989).

${ }^{9} \mathrm{O}$. Kubaschewski and C. B. Alcock, Metallurgical Thermochemistry, 5th ed. (Pergamon, Oxford, 1979), p. 268.

${ }^{10}$ M.-A. Nicolet and S. S. Lau, in VLSI Electronics: Microstructure Science, edited by N. Einspruch (Academic, New York, 1983), Vol. 6, p. 329.

${ }^{11}$ T. B. Massalski, Binary Alloy Phase Diagrams (American Society for Metals Park, Ohio, 1986).

${ }^{12}$ A. M. Brown and M. F. Ashby, Acta Metall. 24, 1088 (1980).

${ }^{13}$ J. K. Howard, R. F. Lever, P. J. Smith, and P. S. Ho, J. Vac. Sci. Technol. 13, 68 (1976),

${ }^{14}$ M. Wittmer, F. LeGoues, and H.-C. W. Huang, J. Electrochem. Soc. 132, 1450 (1985).

${ }^{15}$ E. G. Colgan and J. W. Mayer, Mater. Res. Soc. Symp. Proc. 54, 121 (1986).

${ }^{16}$ E. G. Colgan, M. Nastasi, and J. W. Mayer, J. Appl. Phys. 58, 4125 (1985).

${ }^{17}$ E. G. Colgan, J. Appl. Phys. 62, 2269 (1987)

${ }^{18}$ E. G. Colgan, J. Appl. Phys. 62, 1224 (1987).

${ }^{19}$ G. Majni, C. Nobili, G. Ottaviani, M. Costato, and E. Galli, J. Appl. Phys. 52, 4047 (1981).

${ }^{20}$ S. U. Campisano, G. Foti, E. Rimini, S. S. Lau, and J. W. Mayer, Philos. Mag. 31, 903 (1975).

${ }^{21}$ G. Majni, G. Ottaviani, and E. Galli, J. Cryst. Growth 47, 583 (1979),

${ }^{22}$ J. M. van den Berg and R. A. Hamm, J. Vac. Sci. Technol. 19, 156 (1981).

${ }^{23}$ F. R. de Boer, R. Boom, W. C. M. Mattens, A. R. Miedema, and A. K. Niessen, Cohesion in Metals, edited by F. R. de Boer and D. G. Pettifor (North Holland, Amsterdam 1988), Vol. 1 of the Series on Cohesion and Structure.

${ }^{24}$ I. Barin, O. Knacke, and O. Kubaschewski, Thermochemical Properties of Inorganic Substances, Supplement (Springer, Berlin, 1977).

${ }^{25}$ R. Hultgren, P. D. Desai, D. T. Hawkins, M. Gleiser, and K. K. Kelley, Selected Values of the Thermodynamic Properties of Binary Alloys (American Society for Metals, Metals Park, OH, 1973).

${ }^{26}$ P. J. Spencer, At. Energy Rev. Spec. Issue 8, 9 (1981).

${ }^{27}$ L. Brewer and R. H. Lamoreaux, At. Energy Rev. Spec. Issue 7, 11 (1980).

${ }^{28}$ I. Shilo, H. F. Franzen, and R. A. Schiffman, J. Electrochem. Soc. 129, 1608 (1982).

${ }^{29}$ R. Ferro and R. Capelli, Atti Accad. Naz. Lincei Cl. Sci. Fis. Mat. Nat. Rend. 34, 659 (1963).
${ }^{30}$ R. Ferro, A. Capelli, A. Borsese, and G. Centineo, Att. Accad. Naz. Lincei Cl. Sci. Fis. Mat. Nat. Rend. 45, 54 (1968).

${ }^{31}$ R. J. Kematick and H. F. Franzen, J. Solid State Chem. 54, 226 (1984).

${ }^{32}$ S. P. Murarka, I. A. Blech, and H. J. Levinstein, J. Appl. Phys. 47, 5175 (1976).

${ }^{33}$ M. Nastasi, L. S. Hung, and J. W. Mayer, Appl. Phys. Lett. 43, 831 (1983).

${ }^{34}$ E. G. Colgan, Mater. Sci. Rep. 5, 1 (1990); E. G. Colgan, Ph.D. thesis, Cornell University, Ithaca, NY, 1987.

${ }^{35}$ J. K. Howard, J. F. White, and P. S. Ho, J. Appl. Phys. 49, 4083 (1978).

${ }^{36}$ J. K. Howard, W. K. Chu, and R. F. Lever, Ion Beam Surface Layer Analysis, edited by O. Meyer, G. Linker, and F. Kapeller (Plenum, New York, 1976), Vol. 1, p. 125.

${ }^{37}$ M. B. Chamberlain, J. Vac. Sci. Technol. 16, 339 (1979).

${ }^{38}$ H. C. W. Huang and M. Wittmer, Mater. Res. Soc. Proc. 25, 157 (1984).

${ }^{39}$ R. F. Lever, J. K. Howard, W. K. Chu, and P. J. Smith, J. Vac. Sci. Technol. 14, 158 (1977).

${ }^{40}$ E. G. Colgan and J. W. Mayer, J. Mater. Res. 4, 815 (1989).

${ }^{41}$ J. E. E. Baglin and F. M. d'Heurle, Ion Beam Surface Layer Analysis, edited by $O$. Meyer, G. Linker and F. Kappeler (Plenum, New York, 1976), Vol. 1, p. 385.

${ }^{42}$ U. Koster, P. S. Ho, and M. Ron, Thin Solid Films 67, 35 (1980).

${ }^{43}$ J. W. Liaw, Y.-C. Liu, J. S. Maa, W. S. Hsu, W. J. Shen, and S. K. H Siung, Tsai Liao K'o Hsueh 12, 36 (1980).

${ }^{44}$ K. Nakamura, S. S. Lau, M.-A. Nicolet, and J. W. Mayer, Appl. Phys. Lett. 28, 277 (1976).

${ }^{45}$ I. Krafesik, J. Gyulai, C. J. Palmström, and J. W. Mayer, Appl. Phys. Lett. 43, 1015 (1983).

${ }^{46}$ J. Tardy and K. N. Tu, Phys. Rev. B 32, 2070 (1985).

${ }^{47}$ M. Eizenberg, R. D. Thompson, and K. N. Tu, J. Appl. Phys. 53, 6891 (1982).

${ }^{48}$ T. G. Finstad, G. Salomonsen, N. Norman, and J. S. Johannessen, Thin Solid Films 114, 271 (1984).

${ }^{49}$ G. J. van Gurp, J. L. C. Daams, A. van Oostrom, L. J. M. Augustus, and Y. Tamminga, J. Appl. Phys. 50, 6915 (1979).

${ }^{50}$ M. Kitada and N. Shimizu, J. Mater. Sci. 19, 1339 (1984).

${ }^{51}$ R. K. Ball and A. G. Todd, Thin Solid Films 149, 269 (1987).

${ }^{52}$ K. R. Coffey, L. A. Clevenger, K. Barmak, D. A. Rudman, and C. V. Thompson, Appl. Phys. Lett. 55, 852 (1989).

${ }^{53}$ E. Ma and M.-A. Nicolet, Phys. Status Solidi A 110, 509 (1988).

${ }^{54}$ X. A. Zhao, E. Ma, H. Y. Yang, and M. A. Nicolet, Thin Solid Films 153, 379 (1987). 